\title{
Entrepreneurial Orientation, Innovation and Performance of Value-system Actors
}

\author{
Simon Kamuri \\ Department of Entrepreneurship, Technology, Leadership and Management (ETLM) \\ School of Business and Entrepreneurship (SOBE) \\ College for Human Resource and Development (CORHED) \\ Jomo Kenyatta University of Agriculture and Technology, Nairobi CBD Campus, Kenya \\ kamurisimon@gmail.com \\ OCRID ID: 0000-0002-3368-8011 \\ Accepted: August 2, $2021 \quad$ Published: November 23, 2021 \\ doi:10.5296/jebi.v8i2.19227 \\ URL: https://doi.org/10.5296/jebi.v8i2.19227
}

Received: July 10, 2021

\begin{abstract}
The purpose of this study was to explore entrepreneurial orientation as a cognitive construct attributable to individuals and its relationship with innovation and performance from an industry ecosystem perspective. The study adopted a mixed design approach involving exploration of the factors and a diagnosis of their hypothesized relationships. A mixed sampling of members of a leather industry association and the linked industry institutions was carried out with a 76\% response rate achieved. Quantitative data was collected from key decision-makers as informants of firms in Kenya's leather industry using a questionnaire for guided interviews. The Delphi Technique and a pilot study (Cronbach's Alpha $0.700-0.772$ ) were used to establish instrument reliability. Factor analysis was performed on the study variables using Principal Component Analysis before inferential analysis. Entrepreneurial orientation showed validity as a second-order latent construct comprising three cognitive dimensions, namely vision for growth, opportunity recognition and calculated risk-taking. Entrepreneurial orientation and its antecedents were established as determinants of performance of value-system actors in an industry $\left(\mathrm{R}^{2}=0.422, \mathrm{~F}=13.417, p=0.000\right)$. It further showed that this relationship is partially mediated by innovation by the firms (Sobel test $\mathrm{Z}$-value $=3.30449610, p=0.00095147)$. The study recommends extension of this research to other industries.
\end{abstract}

Keywords: entrepreneurial orientation, vision for growth, opportunity recognition, calculated risk-taking, innovation, performance, value-system actors, leather industry, entrepreneurial ecosystem 


\section{Introduction}

\subsection{Entrepreneurship and Kenya's Leather Industry}

Entrepreneurship plays a crucial social and economic development role notably in exploiting physical and knowledge resources, job creation, export growth and has received increasing attention globally and in Kenya (RoK, 2007; Nafukho \& Muyia, 2010; Acs, Szerb \& Autio, 2015). According to Welter (2010), higher contextual levels of analysis (political or economic system) can show interaction with lower levels such as individual (opportunities identified by the entrepreneur) and context-specific outcomes can contribute to a better understanding of the entrepreneurship phenomena. As an example, the study by Cohen (2006) on community interactions shows the need for higher contextual levels of analysis beyond the firm. Further, Cohen (2006) observes that entrepreneurial ecosystems are hotbeds of innovations. The importance and need to understand entrepreneurial ecosystems as a growing body of knowledge whose concepts, composition and interactions are emerging has been noted by Shwetzer, Maritz and Nguyen (2019).

Meanwhile, there exists a scholarly confusion about the dimensions of the much-studied entrepreneurial orientation. There is no agreement on its cognitive versus behavioural measurements, nor its attribution to individuals versus firms. However, determination of firm performance by entrepreneurial orientation is generally agreed upon. As a result, the entrepreneurial orientation construct has continued to attract research interest (Rauch, Wiklund, Lumpkin and Frese, 2009; Sahban, Kumar \& Ramalu, 2014). In most studies entrepreneurial orientation is measured using individual attributes but presented as an enterprise characteristic. By using dimensions that largely identified with individual characteristics of entrepreneurs, such as risk-taking, pro-activeness, innovativeness and opportunity recognition, researchers have acknowledged the individual nature of entrepreneurial orientation in determining firm or enterprise-level performance. There has been suggestions and empirical evidence for entrepreneurial orientation as an individual, rather than firm-level trait (Rauch \& Frese, 2007; Bolton \& Lane, 2011). Meta-analysis by Rauch and Frese (2007) in particular firmly asserts the significance of individual personality traits in business creation and success. There is need therefore for studies that firmly attribute entrepreneurial traits to the individual rather than the enterprise or other factors. In addition, most entrepreneurial orientation studies have relied on a three-factor model presented by Miller (Rauch et al., 2009), and a five-factor model by Lumkin and Dess (1996). In these models, and to the best of the researcher's knowledge, little attention has been paid to vision as a factor of entrepreneurial orientation. Yet, an entrepreneur's intentions and articulated vision is seen as important in determining entrepreneurial outcomes (Kuratko, 2014; Krueger, Reilly \& Carsrud, 2000; Chi-hsiang, 2015). Innovation is also often studied as a personality trait of "innovativeness" rather than an outcome (Rauch \& Frese, 2007; Rauch et al., 2009).

Further, manufacturing in Africa has continued to perform dismally due to global competitive pressures despite comparative advantages in access to primary inputs. There is an observed paradox of a primary manufacturing industry decried for general poor performance in the face of globalized competition yet having much entrepreneurial opportunity and potential, in an economic region that has need for growth (UNIDO, 2010; MOIT\&C, 2016; Dinh and Clarke, 
2012). This is especially the case in the leather industry (Hansen, Moon \& Mogollon, 2015; Mekonnen et al., 2014; Mwinyihija, 2015; Banga, Kumar \& Cobbina, 2015). In the Common Market for East and Southern Africa region (COMESA) and Kenya in particular, the leather industry is shows unrealized socio-economic performance potential (Mekonnen, Mudungwe and Mwinyihija, 2014). Kenya's leather industry is therefore representative of an industry ecosystem whose entrepreneurial capacity can be premised to influence performance, and ultimately competitiveness in a globalized economic order. A study of the role of entrepreneurial orientation in a Kenyan industry ecosystem would be a useful contribution to the understanding of entrepreneurship especially in a less-studied region.

Developing a clear understanding of entrepreneurial orientation and its outcomes, and finding the link between individual entrepreneurial traits with higher levels of industry, economic performance or competitiveness beyond the enterprise is therefore important. This study set out to investigate the relationship between entrepreneurial orientation and the innovation and performance outcomes of entrepreneurship amongst value-system actors in Kenya's leather industry. Value-system actors are ecosystem players involved in value-addition in the leather production chain. Mwinyihija (2015) and Hansen et al. (2015) identified producers (livestock breeders), butchers, hides and skins traders, tanners, footwear and leather goods manufacturers as players in the value-chain. Given that livestock breeding, butchers and production of hides and skins are considered agricultural activities (United Nations, 2008), industry boundaries for this study were defined by manufacturing of leather - from tanning to finished leather goods, and the related support activities.

\subsection{Literature Review}

\subsubsection{The Entrepreneurial Orientation Construct}

The composition, measurement and dimensions of entrepreneurial orientation as a construct has continued to be the subject of scholarly deliberation. Entrepreneurial orientation studies have led to two major models: Rauch et al. (2009) discuss innovativeness, risk-taking and pro-activeness as the three critical dimensions of entrepreneurial orientation attributed to Miller in 1983 as determinants of firm performance. There is also a five-factor model comprising innovation, pro-activeness and risk-taking, competitive aggressiveness and autonomy, which is attributed to Lumpking and Dess (1996). Zhang, Zhang, Cai, Li, Huang and $\mathrm{Zu}$ (2014), citing Covin and Lumpkin (2011) study, observe that scholars have not agreed whether entrepreneurial orientation should be studied as a behavioural or dispositional construct. Behaviours are action-oriented while dispositions are tendencies or inclinations. Lomberg, Urbig, Stockmann, Marino and Dickson (2016) observed that entrepreneurial orientation is studied as both a uni-dimensional and multidimensional variable with empirically supported positive effects on firm performance. Dimensionality refers to the number of attributes or factors that can be used for measurement of a variable such as a personality trait having one (uni-) or several (multi-) distinct factors.

From an empirical study and support with historical entrepreneurship scholarship, Zhang et al. (2014) conclude that entrepreneurial orientation can be studied as a five-dimensional behavioural construct. They do so having embraced a behavioural perspective. However, from 
psychology studies (PT, 2015), an orientation is a mental disposition rather than a behaviour. In addition, the questions used to validate the model by Zhang et al. (2014) are suggestive of both dispositions and behaviours. Further, often units of observation are individuals but other study aspects (the observations themselves, variables, outcomes) are attributed to firm-level. Thus, the call by Rauch et al. (2009) for further research on alternative approaches to measuring entrepreneurial orientation and its dimensionality remains relevant.

In addition, Lomberg et al. (2016) assert that entrepreneurial orientation is a strategy making process that influences decisions and actions. Having a futuristic imagery has been central to strategy theory (Hamel \& Prahalad, 1996). Rauch et al. (2007) and Rauch et al. (2009) affirmed the significance of vision as a dimension of entrepreneurial orientation. Despite this acknowledgement of role of vision, it has not received enough attention in entrepreneurship studies, least of all as an entrepreneurial orientation variable.

Past studies have shown entrepreneurial orientation factors as positively correlated with or as determinants of entrepreneurial outcomes in diverse industries, especially performance. Bakar and Zainol (2015) observed that vision, innovation, pro-activeness and risk-taking have a positive and significant relationship with performance of SMEs in Nigeria. Commonly studied dimensions of entrepreneurial orientation have been shown to influence performance of SMEs in different industries, such as in Sweden (Kreiser, Marino, Kuratko \& Weaver, 2012) and Netherlands (Kraus, Rigtering, Hughes, \& Hosman, 2012). Rauch et al. (2009) showed that entrepreneurial orientation correlated positively with financial and non-financial performance indicators of firms. Al-Ansari (2014) and Acs et al. (2015) have argued that innovation is a path to business growth performance.

This study blends the entrepreneurial orientation (EO) construct with contributions of various authors as a basis for refining the construct as an individual personality trait. It adopts Ruach et al., (2009) risk taking propensity as a key construct in entrepreneurial orientation then complements this with additional two dimensions; namely opportunity recognition and vision for growth. The entrepreneurial orientation construct used in this study was conceptualized as a psychological disposition construct comprising envisioning (Ensley, Carland, \& Carland, 2000; Amstrong \& Hird, 2009; Gupta and Gupta, 2013; McMullan \& Kenworthy, 2015), opportunity recognition (Shane, 2000; Wasdani \& Mathew, 2014; Acs et al., 2015) and calculated risk-taking (Zhao, Seibert, \& Lumpkin, 2010; Acs et al., 2015).

\subsubsection{Innovation}

Literature shows that innovation is either taken as an outcome in entrepreneurship, often as moderating or, as in this study, a mediating variable of entrepreneurial performance. Innovation is seen as and as central to entrepreneurial endeavours. Scholars identify innovation as the conversion of ideas into (usable) solutions that can be applied (Bjerke, 2007; Kuratko, 2014). In his conceptualization of entrepreneurship, Bjerke (2007) avers that creativity, innovation and entrepreneurship are linked as follows: creativity comes up with new ideas, innovation applies these new ideas while entrepreneurship is coming up with new applications which others can use as well to fill a need and / or satisfy some demand, whether existing or created. The practice of innovation is a path to firm growth performance, fortifies economic growth and offers solutions to economic and social challenges (Al-Ansari, 2014). Dinh and 
Clarke (2012) empirical study confirm that innovation is associated with better firm performance.

Keeley, Walters, Pikkel and Quinn (2013) discuss ten types of innovation ranging in focus from internal to external in terms of distance from customer experiences. Seven types of innovation can be gleaned from literature cited above and are hereby paraphrased by the researcher. These are input innovations (introducing new sources of raw material or inputs in a process), product innovations (a new or improved product offering), process innovation (new procedures for production), management innovations (administrative procedures and policies), organizational innovations (new organizational forms, structures or cultures), delivery innovations (new ways of delivering value, including peripheral support services) and system innovations (changes in system components relationships in a bigger entity).

Kollmann and Stockmann (2012) drew on theoretical knowledge of entrepreneurial orientation, exploratory and exploitative innovation and the resource-based view of the firm to provide empirical evidence for the entrepreneurial orientation-innovativeness-performance link in 228 ICT firms. Kollmann and Stockmann (2012) found that exploratory and exploitative innovation, as behaviour rather than an orientation, mediated the link between entrepreneurial orientation variables and firm performance (innovativeness through exploration and exploitation; risk-taking through exploration; pro-activeness through exploration and exploitation).

\subsubsection{Performance of Value-system Actors}

Foundations of firm performance measures in entrepreneurship studies were laid by Lumpkin and Dess (1996) as: sales growth, market share, profitability, overall performance and shareholder satisfaction. Lumpkin and Dess (1996) advocate for use of multiple and broad performance dimensions as growth-induced resource demand may lead to a favourable outcome on one measure and an unfavourable outcome the other (for example, investment increasing market share while reducing profitability). Meta-analysis by Rauch et al. (2009) give a guide to the types of firm-level measures used for performance as a variable dependent on entrepreneurial orientation.

Al-Ansari (2014) showed that business growth performance is mediated by innovation practices in Dubai SMEs. Ming and Yang (2009) used entrepreneurial satisfaction and innovative capability as performance measures and found that these variables relationship with firm performance had a high score. Using quality as a performance measure, Ndubisi and Iftikhar (2012) found entrepreneurship (variables applied of risk-taking, pro-activeness and autonomy are associated with the entrepreneurial orientation trait) is positively correlated with firm performance. McMullan and Kenworthy (2015) records empirical studies showing the relationship between entrepreneurial creativity and innovation (eleven studies) and with business growth and financial performance (38 studies). The studies show that entrepreneurial outcomes of innovation and business development (growth and financial performance) favour a positive relationship with entrepreneurial creativity.

The determinants of industry performance discussed by Mwinyihija (2015) include human resource development, entrepreneurship, enterprise productivity, technological development, 
infrastructure, quality standards and testing, research and development and support services through government interface with business. Using nine measurement criteria that accommodate different approaches in this study allows for flexibility and applicability to diverse contexts, including subjective self-reported measures similar to the study by Ming and Yang (2009).

\subsubsection{Critique of Existing Literature on Entrepreneurship in Industry Ecosystems}

Literature shows attribution of entrepreneurial characteristics to firms. However, the measures used are individual traits and behaviours which are linked then to firm-level performance. Therefore, there is need to delineate entrepreneurship as an individual phenomenon (Rauch \& Frese, 2007) rather than a firm characteristic. Individual entrepreneurial characteristics (traits and behaviours) can then be linked not only to the firm but also to the industry level as an entrepreneurial ecosystem. There has also been a mix-up of cognitive dispositions and behavioural competences in entrepreneurship studies (Jain, 2011; Lans, Verstegen, \& Mulder, 2011; Kollmann \& Stockmann, 2012).

Despite performance and innovation being identified as entrepreneurial outcomes, there is no uniformity or full clarity of measures to be used for either variable. For performance, there is an over-reliance on financial measures. For innovation, new perspectives of business model innovation have been added recently to the traditional tangible measures of product and process innovations. The importance of understanding diverse players in industry or entrepreneurial ecosystems is only gaining momentum in scholarship (Audretsch, 2007; Nambisan \& Baron, 2012; Kshetri, 2014).

The importance of an ecosystem perspective of entrepreneurship is indicated in recent studies (Shwetzer et al., 2019). In studying interactions of entrepreneurship pillars in economies, Acs, et al. (2015) Global Entrepreneurial Index (GEI) studies direct understanding of entrepreneurship to a system linkages (meso-level) approach. According to Valentinov and Chatalova (2016), functionally differentiated systems (economy, politics, law) are a key attribute of civilization and modern society. Cohen (2006) discusses various elements including interconnected actors, infrastructure, formal and informal networks and culture that interact to form a sustainable ecosystem of entrepreneurial innovations. Colapinto and Porlezza (2012) show the importance of overlapping interaction of diverse actors in creative industries of a knowledge economy. A conceptual model of the hypothesized relationship between the study variables is shown in Figure 1.

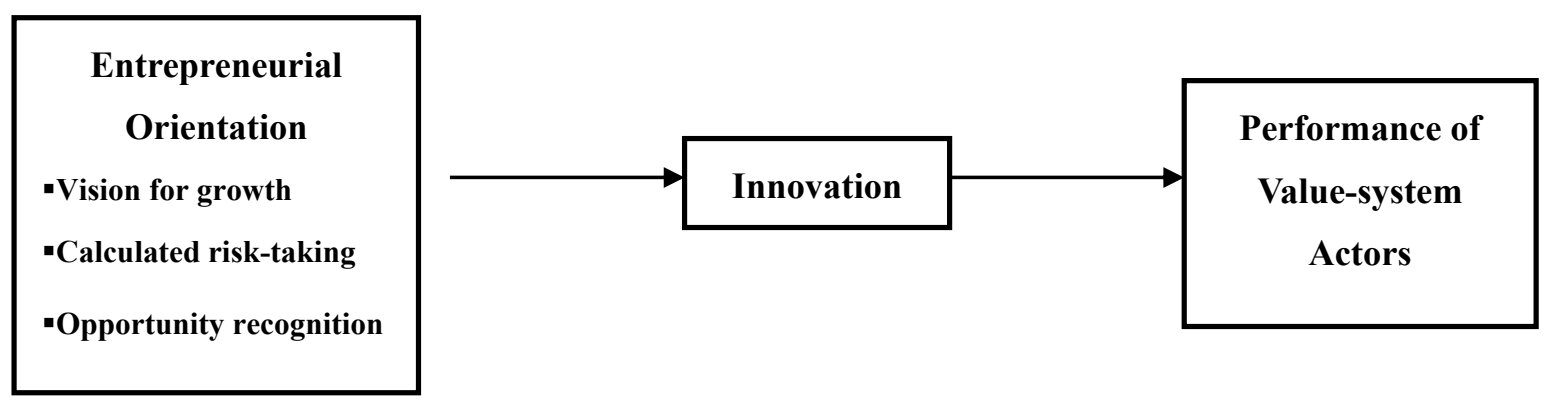




\subsection{Research Objectives and Hypotheses}

This research set out to investigate the relationship between entrepreneurial orientation and the outcomes of innovation and performance amongst value-system actors in Kenya's leather industry. The specific objectives were:

1. To determine the relationship between entrepreneurial orientation and performance of value-system actors in Kenya's leather industry.

2. To determine the mediating effect of innovation by value-system actors in the relationship between entrepreneurial orientation and performance Kenya's leather industry.

From the objectives of the study, the following research hypotheses were formulated:

1. $\mathbf{H}_{\mathbf{a} 1}$ : Entrepreneurial orientation determines performance of value-system actors in Kenya's leather industry.

2. $\mathbf{H}_{\mathbf{a} 2}$ : Innovation mediates the relationship between entrepreneurial orientation and performance of value-system actors in Kenya's leather industry.

\section{Method}

A cross-sectional survey was performed using a heterogeneous population of 68 value-system actors comprising members of the Nairobi-based Leather Articles Entrepreneurs Association (LAEA) and associated industry support institutions. Mixed sampling was applied involving a census fifty-eight LAEA members, with the membership list forming the primary sampling frame, and snowballing from 10 industry support institutions. Diverse value-system actor roles such as processors, delivery agents, industry network associations, regulators and research agents were included as described by Hansen et al. (2015).

Data was collected in April - June 2018 by the researcher and an assistant from respondents at their premises and during an industry networking meeting. A questionnaire was designed by the researcher by adapting items from previous studies to collect quantitative data. Entrepreneurial orientation measures were adapted from Bolton and Lane (2012) and the Carland Entrepreneurial Index (CEI) (Carland, Carland and Ensley, 2002) as applied by Amstrong and Hird (2009). Measures for innovation were adapted from Keeley et al. (2013) while performance items were adapted from the work of various scholars (Santos \& Barito, 2012; Ming \& Yang, 2009; Al-Ansari, 2014; Stephan, Hart, \& Drews, 2015).

Independent and mediating variables were coded as scores on a five-point Likert scale showing the level of agreement with measurement items. The dependent performance variable was measured using pluses $(+)$ and minuses (-) to show changes over five years. These responses were coded on a five-point Likert scale ranging from a Large increase (5), no change (3) to a large decrease (1) in performance. Items worded to measure negative proxies of desired performance (such as changes in operating expenses for business cost efficiencies, product defects for product quality, and customer complaints for stakeholder/customer satisfaction respectively) were coded in the reverse order. First-order latent variables were scored using an index of average score from indicator items. Similarly, first-order variables were averaged 


\section{Macrothink}

Journal of Entrepreneurship and Business Innovation

ISSN 2332-8851

2021, Vol. 8, No. 2

to obtain an index for the second-order latent entrepreneurial orientation variable (Neuman, 2009; Kothari \& Gaurav, 2014).

Analysis involved exploration of factors and diagnosis of relationships between them in Kenya's leather industry (Kothari \& Gaurav, 2014; Bless, Higson-Smith \& Kagee, 2006). Thus, entrepreneurial orientation, innovation and performance constructs were refined through factor analysis as entrepreneurship variables, before diagnostic tests aimed at revealing the relationship between them were carried out. Exploratory Data Analysis (EDA) was performed to assure the soundness of measurement, coding procedures and compounding indices. EDA entailed descriptive statistics and tests of statistical assumptions such as measurement validity and reliability, normality of data distribution, linearity, lack of multi-collinearity and homoscedasticity of the variables (Garson, 2012). Exploratory Factor Analysis (EFA) was used to establish the discriminant and convergent validity of the constructs used, before inferential analysis was performed (Costello \& Osborne, 2005). The $t$-test was applied to find whether the correlations between independent variable and the mediating and dependent variables respectively were significant (at $p<0.05$ ) in showing the (regression) relationship between variables in the population (Bryman, 2012). Statistical Package for Social Sciences (SPSS) version 21 was applied in the analysis of data. A pilot study was conducted on seventeen Micro, Small and Medium Enterprise (MSME) owners at Kariokor Market leather cluster (Hansen et al., 2015) to test the data collection instrument for reliability. Subjects of the pilot study were not included in the main research.

\section{Results}

\subsection{Results of the Pilot Study}

As shown in Table 1, results showed the instrument to be reliable with the measurement items meeting the 0.7 Cronbach's Alpha threshold for retention (Garson, 2012). The entrepreneurial orientation variable was measured using fifteen indicators in three sub-variables (vision for growth had four, opportunity recognition had 6 and calculated risk-taking had 5) with reliability indices of $0.739,0.772$ and 0.700 respectively. Innovation and performance were measured using nine items each with Cronbach Alpha values of 0.761 and 0.717 respectively. 
Table 1. Reliability Results for the entrepreneurial orientation, innovation and performance variables

Variable / Sub-variable

Cronbach's Alpha

Comment

Entrepreneurial Orientation

Vision for Growth

Reliable

Opportunity Recognition

0.772

Reliable

Calculated Risk taking

0.700

Reliable

Innovation

0.761

Reliable

Performance

0.717

Reliable

\subsection{Demographic Statistics}

Fifty-two valid questionnaires were obtained from the main study for analysis giving a response rate of $76 \%$. Respondents were leaders of value-system actors in the industry as key-informants. Fifty-six percent of the respondents' firms were micro-enterprises (less than ten employees) and 37\% were small enterprises as (10 to 50 people) according to the Kenyan Micro and Small Enterprises Act of 2012 classification (RoK, 2012). Mwinyihija (2015) states that only a few of the leather manufacturers operating in Kenya are considered medium enterprises, the majority are considered small and micro enterprises and most are informal to avoid the tax burden. Respondents represented five industry value-system roles (Hansen et al., 2015), including tanners (producers at 9.6\%), leather-goods manufacturers (processors at $635 \%$ ), leather suppliers (delivery agents at 19.2\%), LAELA officials (industry network association at 3.8\%), the Kenya Leather Development Council, KLDC (policy regulators at $1.9 \%$ ) and the Training and Production Center for the Shoe Industry, TPCSI (research agents at $1.9 \%)$.

\subsection{Descriptive Statistics for Study Variables}

A summary of measurement item scores on a five-point Likert-scale for the study variables are shown in Table 2. The respondents had had high levels of Vision for Growth for their enterprises at 4.22 rating ( $\mathrm{SD}=0.747, \mathrm{n}=52$ ). Kantabutra and Avery (2010) study, itself affirming earlier studies by Baum and colleagues (Baum, Locke and Smith, 2001), states the importance of having a vision statement with characteristics and content such as future orientation, clarity and challenge - in this case growth - in determining performance. Mohammed, Ibrahim and Shah (2017) found that strategic competency (which was described in terms of identifying, setting and acting on long-term goals) of Nigerian women micro-entrepreneurs had a direct positive and significance effect on firm performance $(\beta=$ $0.227, \mathrm{t}=3.411, p<0.01)$. 


\section{Mll Macrothink}

Journal of Entrepreneurship and Business Innovation

ISSN 2332-8851

2021, Vol. 8, No. 2

The average opportunity recognition score was $4.13(\mathrm{SD}=0.568, \mathrm{n}=52)$ which was a high rating indicating that on average, the respondents had high levels of Opportunity Recognition. Santos, Caetano, Baron and Curral (2015) showed that there are cognitive frameworks used by individuals to recognize business opportunities thus offering an explanation for business success. Baron and Ensley (2006) aver that opportunity recognition is a cognitive process of recognizing patterns allowing identification of new business opportunities. Yang (2009) showed that firms with high opportunity recognition had higher innovative capability than passive, proactive or creative firms.

The average score for calculated risk-taking was $3.6(\mathrm{SD}=1.070, \mathrm{n}=52)$ which was above average indicating that on average, the respondents had high levels of Calculated Risk-taking. Sahban et al. (2014) used such indicators of risk-taking as making decisive and risky action, making decision in uncertainty/venturing into the unknown/proclivity for high risk, and borrowing heavily to which parallels can be drawn with this study's indicators of Affinity for Bold Action, Tendency to Take Risks and Willingness to Borrow respectively. Poutziouris (2010) found that risk-taking intensity positively correlates with business sales performance in UK family firms.

The score for innovation was $4.10(\mathrm{SD}=0.505, \mathrm{n}=52$ ) which was a high rating indicating that on average, the respondents reported that their firms had high levels of innovation. This was especially the case in finding new markets but innovation was least in introducing system-level partnerships. Various scholars avow the importance of innovation and its relationship to performance in Small and Medium Enterprises (SMEs) (Ngugi, Mcorege \& Muiru, 2013; Al-Ansari, 2014), especially manufacturing firms in Africa (Dinh and Clarke, 2012).

Item scores on performance of value-system actors had an average score of 3.47 ( $\mathrm{SD}=0.647$, $\mathrm{n}=52$ ). This was a high rating indicating that on average, the respondents reported that their firms had high levels of performance. The importance of performance as an attribute of business ventures is affirmed by various scholars (Kraus et al., 2012; Dinh \& Clarke, 2012;

Mwinyihija, 2015).

Table 2. Descriptive statistics for the study variables

\begin{tabular}{lll}
\hline Study Variable & Mean Score & Std. Dev. \\
\hline Vision for Growth & 4.22 & .747 \\
Opportunity Recognition & 4.13 & .568 \\
Calculated Risk-taking & 3.6 & 1.070 \\
Innovation & 4.10 & .505 \\
Performance & 3.47 & .647 \\
\hline
\end{tabular}




\subsection{Factor Analysis on the Study Variables}

Exploratory factor analysis was employed using Principal Component Analysis (PCA) with Promax rotation for convergent and discriminant validity. Factor analysis is a systematic method of constructing indices by assessing the contribution of each underlying dimension to each index. Principal Component Analysis (PCA) is a commonly used method of computing factor analysis (Leech, Barret and Morgan, 2005). Factor analysis using PCA was important in validating the constructs to be used for hypotheses testing. According to the Kaiser criterion, factors with an eigenvalue of one or greater from the PCA are retained as the independent or explanatory variable (Sapsford, 2007; Kothari \& Gaurav, 2014). Development of the Carland Entrepreneurial Index (CEI) (Carland et al., 2002) involved use of measurement items from that obtained quantitative scores and applied principal component factor analysis to validate the construct. The results of factor analysis showed entrepreneurial orientation construct had nine indicators that discriminated into sub-scales namely Vision for Growth, Opportunity Recognition and Calculated Risk-taking. Innovation and Performance constructs had nine items that discriminated into two components each.

\subsubsection{Factor Analysis for Entrepreneurial Orientation}

The study revealed that the Kaiser-Meyer-Olkin Measure of Sampling Adequacy for entrepreneurial orientation was 0.752 which was above 0.6 (Kaiser, 1974) making the sample adequate for factor analysis (Bartlett, 1954). Based on Kaiser Criterion, three factors were imputed out of a total 9 indicators. Three factors imputed attained eigenvalues in the initial solution greater or equal to 1.0 . The three factors were able to explain $74.144 \%$ of the total variance for entrepreneurial orientation. (Hair et al., 2014)

As shown in Table 3, the pattern matrix shows the first component was Opportunity Recognition that had three items (Osuccess, Oalertness and Odiscovery) whose factor loadings ranged from 0.812 to 0.901 . The second component was vision for growth that had three items (Vgoals, Vimprovement and Vactions) whose loadings ranged from 0.602 to 0.994 . The third component was calculated risk taking that had three items (Rtendency, Raffinity and Rinvest) whose loadings ranged from 0.623 to 0.897 .

The pattern matrix showed entrepreneurial orientation as a second-order variable as hypothesized. The entrepreneurial orientation (EO) variable showed multi-dimensionality comprising Vision for Growth, Opportunity Recognition, and Calculated Risk-taking as first-order latent variables. Therefore, EO can be studied as a second-order latent construct comprising three first-order latent variables. This was consistent with theoretical postulations of this study and scholarly discourse about cognitive dimensions of entrepreneurship (Puhakka, 2002; Baron \& Ensley, 2006; Florin et al., 2007; Zhang et al., 2014; Sahban et al., 2014; Santos et al., 2015). Multi-dimensionality of entrepreneurial orientation is supported by empirical literature on various constructs (Rauch et al., 2009). The three components of vision for growth, opportunity recognition and calculated risk-taking can be deduced from literature (Ruach et al., 2009; Ensley et al., 2000; Amstrong \& Hird, 2009). Covin and Wales (2012) elaborately discuss the EO measurement models and assert that entrepreneurial orientation can be studied using either formative or reflective measurement models (distinguishing that 'there are no 
formative or reflective constructs, only formative and reflective measurement models').

\subsubsection{Factor Analysis for Innovation}

Exploratory factor analysis was employed on innovation construct that was measured using nine items. The items were introduction of new product offerings, new processes, new organizational capabilities, new organizational forms or structures, new customers/markets, new customer engagements, new partnerships or system interactions, new revenue generation practices and new cost structures.

The study revealed that the Kaiser-Meyer-Olkin Measure of Sampling Adequacy for the innovation construct was 0.720 which was above the 0.6 threshold (Kaiser, 1974). This meant that the sample was adequate for factor analysis. The Chi-Square value for Bartlett's Test of Sphericity was 199.682 with degrees of freedom amount to 36 and $p$-value less than 0.05 indicating suitability of data for structure detection (Bartlett, 1954). Extracted items measuring innovation construct had communalities all greater than 0.5 indicating that the retained items fitted well with other items in the innovation factor solution. Based on Kaiser Criterion, two factors were extracted out of a total 9 indicators. The two factors imputed attained eigenvalues in the initial solution greater or equal to 1.0. The cumulative variability explained by these imputed two factors in the extracted solution for innovation was $60.542 \%$ (Hair et al., 2014).

As shown in Table 3, the pattern matrix shows the first component had five items (InnovCosts, InnovRevenues, InnovSystInteraction, InnovOrgForm and InnovCapabilities) whose factor loadings ranged from 0.578 to 0.871 . The second component had four items (InnovMarkets, InnovCustEngagement, InnovProducts and InnovProcesses) whose loadings ranged from 0.607 to 0.888 .

The pattern matrix shows that innovation can be dichotomous or multi-dimensional variable. The first component of the innovation variable comprises items measuring how the business is modelled in terms of business system or concept (InnovCosts, InnovRevenues, InnovSystInteraction, InnovOrgForm and InnovCapabilities) and are associated with business model, structure or administrative innovation. The second component can be seen as having items measuring the business-customer interface (InnovMarkets, InnovCustEngagement, InnovProducts and InnovProcesses) which are changes associated with products and customers.

The multi-dimensionality of innovation is supported by theoretical and empirical studies (Clauss, 2016; Bashir \& Verma, 2017). Clauss (2016) found three second-order dimensions, namely value creation innovation, value proposition innovation, and value capture innovation. Literature business model innovation (BMI) describe it as the design of novel business-system interactions that determines how a firm does business. BMI was described by Bashir and Verma (2017) as "the process of finding a novel way of doing business which results in reconfiguring of value creation and value capturing mechanisms" which can occur by changing even one element of a business model.

Studying established but entrepreneurial firms, Amit and Zott (2012) identified creating novel activities to be performed (activity system content), new ways of activities' linkage an sequence (activities structure), changing parties that perform activities (activities governance) 
with which parallels to capability innovation (with resultant costs revenues changes), change in organizational form and change in an organization's interaction with the industry system respectively. This is in line with scholarly literature on business model innovation as distinct form of innovation from product and process innovation (Bashir \& Verma, 2017) which are the second component of the innovation variable in this study. Further, Roach, Ryman and Makani (2016) found measures of innovativeness to discriminate into two sub-constructs, namely innovation orientation and product/service innovation. In this study, factor analysis for the innovation variable extracted two dimensions that could be classified as system / configuration changes and customer-interface / content changes.

\subsubsection{Factor Analysis for Performance of Value-system Actors}

Exploratory factor analysis was employed on Performance construct that was measured using nine items. Performance showed discriminant validity as two factors that were dependent on the wording of the measurement questions. The study revealed the Kaiser-Meyer-Olkin Measure of Sampling Adequacy was 0.796 which was above 0.6 (Kaiser, 1974). The Chi-Square value for Bartlett's Test of Sphericity was 325.913 with degrees of freedom amount to 36 and $p$-value less than 0.05 indicating suitability of data for structure detection (Bartlett, 1954). All items measuring the performance construct had communalities greater than 0.5 indicating that the retained items fitted well with other items in the performance of value system factor solution. Based on Kaiser Criterion, two factors were extracted that explained $71.853 \%$ of the total variance in the study data. The two factors imputed attained eigenvalues in the initial solution greater or equal to 1.0 (Hair et al., 2014).

The pattern matrix for business performance showed two components as shown in Table 3. The first component had six items (BusPerformSales, BusPerformQuantity, BusPerformProfit, BusPerformProductivity, BusPerformShare and BuPerformVariety) whose factor loadings ranged from 0.632 to 0.949 . The second component had three items (BusPerformDefects, BusPerformComplaints and BusPerformExpenses) whose loadings ranged from 0.613 to 0.911 .

These results support previous studies on entrepreneurship identify business performance as a dependent variable whose measures include the same indirect measures. Diverse performance measures were used in this study as inductively determined from theoretical and empirical literature (Wiklund \& Shepherd, 2003; 2005; Rauch et al., 2009; Jain, 2011; Sanchez, 2012; Al-Ansari, 2014; Kraus et al., 2012; Ndubisi \& Iftikhar 2012; McMullan \& Kenworthy, 2015).

For the Performance variable, the items with positively stated desired outcome measures of performance (namely improvement in profit, sales, markets, quantity, productivity, and variety) showed convergence as one dimension, while those with negative non-desired / undesirable performance outcomes (reduction in business expenses, defects and customer complaints). Expenses can be considered as an indirect measure of operational and financial performance efficiencies, product defects as proxy measure of product quality and customer complaints as a proxy for stakeholder (in this customer) satisfaction. 
Table 3. Pattern matrices for the study variables

\begin{tabular}{|c|c|c|c|c|}
\hline \multirow[t]{2}{*}{ Variable } & & \multicolumn{3}{|c|}{ Component } \\
\hline & & 1 & 2 & 3 \\
\hline \multirow{9}{*}{$\begin{array}{l}\text { Entrepreneurial } \\
\text { Orientation }\end{array}$} & Osuccess & .901 & & \\
\hline & Oalertness & .829 & & \\
\hline & Odiscovery & .812 & & \\
\hline & Vgoals & & .994 & \\
\hline & Vimprovement & & .905 & \\
\hline & Vactions & & .602 & \\
\hline & Rtendency & & & .897 \\
\hline & Raffinity & & . & 859 \\
\hline & Rinvest & & & .623 \\
\hline \multirow[t]{9}{*}{ Innovation } & InnovCosts & .871 & & \\
\hline & InnovRevenues & .837 & & \\
\hline & InnovSystInteraction & .753 & & \\
\hline & InnovOrgForm & .688 & & \\
\hline & InnovCapabilities & .578 & & \\
\hline & InnovMarkets & & .888 & \\
\hline & InnovCustEngagement & & .823 & \\
\hline & InnovProducts & & .716 & \\
\hline & InnovProcesses & & .607 & \\
\hline \multirow[t]{9}{*}{ Performance } & BusPerformSales & .949 & & \\
\hline & BusPerformQuantity & .937 & & \\
\hline & BusPerformProfit & .885 & & \\
\hline & BusPerformProductivity & .816 & & \\
\hline & BusPerformShare & .812 & & \\
\hline & BuPerformVariety & .632 & & \\
\hline & BusPerformDefects & & .911 & \\
\hline & BusPerformComplaints & & .881 & \\
\hline & BusPerformExpenses & & .613 & \\
\hline
\end{tabular}

Extraction Method: Principal Component Analysis. Rotation Method: Promax with Kaiser Normalization.

a. Rotation converged in 3 iterations. 


\section{Macrothink}

\subsection{Tests for Statistical Assumptions}

Assumptions of normality, heteroscedasticity and multicollinearity were tested to establish suitability of the data for linear regression and statistical modelling (Garson, 2012). Results of the tests for statistical assumptions are presented below. Normality of the data was tested using P-P plots and results showed a normal distribution graph as shown in Figure 2.

\section{Normal P.P Plot of Regression Standardized Residual}

Dependent Variable: Performance_index

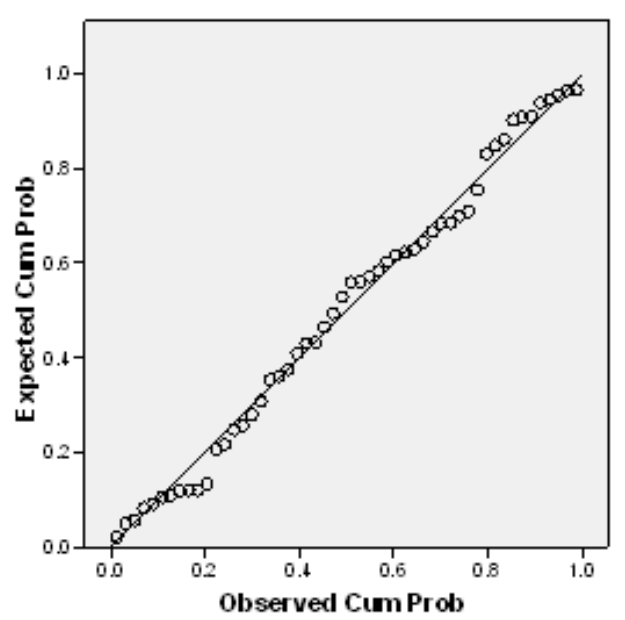

Figure 2. P-P Plot showing results of normality test on the study data

Homoscedasticity assumption was tested using a scatter plot of standardized residuals. As shown in Figure 3, the data had a normal visual distribution that did not show obvious funneling out, indicating that the data met the homoscedasticity assumption.

Scatterplot

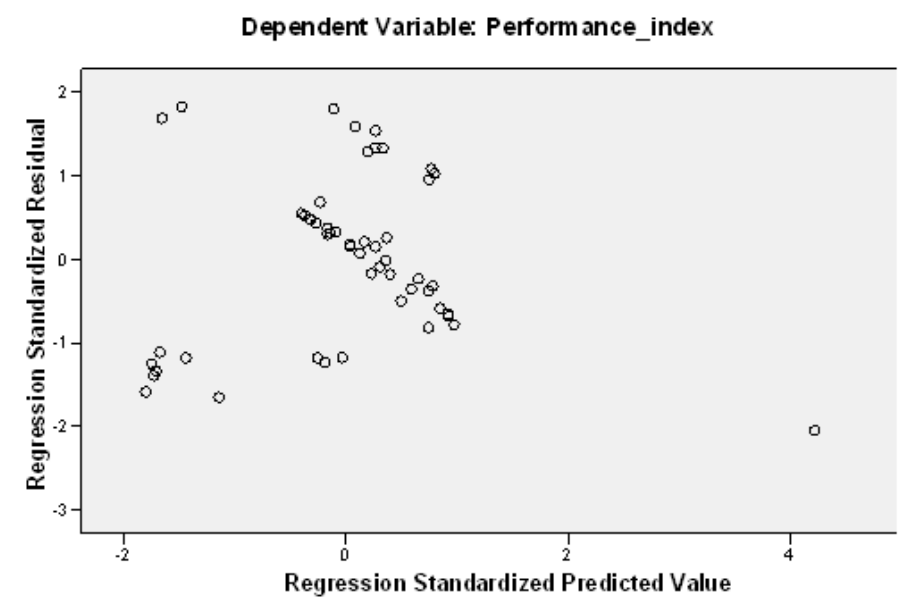

Figure 3. Scatter plot showing results of the test for heteroscedasticity on the study data 


\section{Macrothink}

Journal of Entrepreneurship and Business Innovation

ISSN 2332-8851

2021, Vol. 8, No. 2

Multicollinearity was tested using Variance Inflation Factors (VIF) with an acceptance value of below 10. Table 4 shows the VIF was below 10 indicating that multicollinearity was not a problem.

Table 4. Results of test for multicollinearity

\section{Coefficients(a)}

\begin{tabular}{|c|c|c|c|c|c|c|c|c|}
\hline \multirow[t]{2}{*}{ Model } & & \multicolumn{2}{|c|}{$\begin{array}{l}\text { Unstandardized } \\
\text { Coefficients }\end{array}$} & $\begin{array}{l}\text { Standardized } \\
\text { Coefficients }\end{array}$ & \multirow{2}{*}{$\begin{array}{l}\mathrm{t} \\
\text { Toleranc }\end{array}$} & Sig. & \multicolumn{2}{|c|}{$\begin{array}{l}\text { Collinearity } \\
\text { Statistics }\end{array}$} \\
\hline & & B & $\begin{array}{l}\text { Std. } \\
\text { Error }\end{array}$ & Beta & & VIF & B & $\begin{array}{l}\text { Std. } \\
\text { Error }\end{array}$ \\
\hline \multirow[t]{2}{*}{1} & (Constant) & 1.706 & .366 & & 4.666 & .000 & & \\
\hline & $\begin{array}{l}\text { Entrepreneuria } \\
\text { 1_orientation }\end{array}$ & 1.188 & .184 & .675 & 6.476 & .000 & $\begin{array}{l}1.00 \\
0\end{array}$ & 1.000 \\
\hline
\end{tabular}

a Dependent Variable: Performance_index

\subsection{Test for Hypotheses}

Linear regression was applied to test the hypotheses on the relationships between entrepreneurial orientation, innovation and performance. Entrepreneurial orientation as a second-order variable was regressed on performance and results interpreted using adjusted $\mathrm{R}^{2}$ values and $p$-values at $p<0.05$ significance level (2-tailed). The mediating effect of innovation on relationship between entrepreneurial orientation and performance was also tested using the causal step analysis for mediation by Baron and Kenny's (Kenney, 2016).

3.6.1 Relationship between Dimensions of Entrepreneurial Orientation and Performance of Value-system Actors

The first objective of the study was to determine the relationship between entrepreneurial orientation and performance of value-system actors in the leather industry in Kenya. The following null hypothesis was formulated:

$\mathbf{H}_{01}$ : Entrepreneurial orientation does not determine performance of value-system actors in Kenya's leather industry.

$\mathbf{H}_{\mathbf{a} 1}$ : Entrepreneurial orientation determines performance of value-system actors in Kenya's leather industry.

Table 5 shows the results of stepwise multiple linear regression analysis for dimensions of Entrepreneurial Orientation on Performance. Sequential regression of Vision for Growth, Opportunity Recognition and Calculated Risk-taking. The three Entrepreneurial Orientation indicators accounted for $42.2 \%$ of variation in Performance (Adjusted $\mathrm{R}^{2}=0.422$ ) and that this relationship is significant $(\mathrm{F}=13.417, p=0.000)$. Every addition of a new independent variable 
progressively increased the combined influence on Performance from 27.7\% (Adjusted $\mathrm{R}^{2}=0.277$ ), through $32.5 \%$ (Adjusted $\mathrm{R}^{2}=0.325$ ) to $42.2 \%$ (Adjusted $\mathrm{R}^{2}=0.422$ ) thus showing the importance of each in coherence with theoretical assertions. The regression model equation obtained from coefficients was:

$$
\text { Performance }=2.655+0.629 \text { Vision for growth }+0.447 \text { Calculated Risk-taking }-1.077
$$

\section{Opportunity Recognition}

The beta coefficients for the independent Entrepreneurial Orientation variables changed with addition of each new variable and each had a unique contribution to variance in the dependent Performance variable. These statistics indicated that unit increases in Vision for Growth, Calculated Risk-taking and Opportunity Recognition would result in 0.629, 0.447 and -1.077 changes respectively in performance of value system actors in Kenya's leather industry. Thus, the Entrepreneurial Orientation variables of Vision for Growth and Calculated Risk-taking increased Performance of value-system actors in Kenya's leather industry while Opportunity Recognition had a reducing effect.

When analyzed together Vision for Growth, Opportunity Recognition and Calculated Risk-taking as entrepreneurial orientations of value-system actors, collectively determine performance in Kenya's leather industry. The combined effect of the three factors on performance was forty-two per cent with the rest being determined by exogenous factors. Rauch et al. (2009) meta-analysis and (Wales, 2016) discuss entrepreneurial orientation and its commonly studied dimensions as strategic posturing that determines performance of firms but that can have diverse economic outcomes. While Zhang et al. (2014) embrace and support the application of a five-dimension behavioural EO model, this study departs from it by demonstrating a cognitive or dispositional model. Empirical evidence from this study suggests that it is possible to study individual-level EO as a three-factor latent construct of the cognitive mould.

Therefore, the identification of Vision for Growth (from strategic management studies), Opportunity Recognition and Calculated Risk-taking (from cognitive approaches of entrepreneurship studies) as dimensions of entrepreneurial orientation is justified. This study further links the factor to outcome variables associated with not only the firms but also an industry. Zhang et al. (2014) acknowledge the need to develop appropriate EO measures at various levels including societies, nations, industries, firms, groups and individuals. This study therefore contributes to expanding scholarly conversation and understanding of entrepreneurship especially cognitive dimensions of the entrepreneurial orientation variable. 
Table 5. Regression results for the effect of dimensions of entrepreneurial orientation on performance (Stepwise)

\section{Coefficients $^{\mathrm{a}}$}

\begin{tabular}{|c|c|c|c|c|c|c|}
\hline & & \multicolumn{2}{|c|}{$\begin{array}{l}\text { Unstandardized } \\
\text { Coefficients }\end{array}$} & \multicolumn{3}{|c|}{$\begin{array}{l}\text { Standardized } \\
\text { Coefficients }\end{array}$} \\
\hline \multicolumn{2}{|c|}{ Model } & B & Std. Error & Beta & $\mathbf{T}$ & Sig. \\
\hline \multirow[t]{2}{*}{1} & (Constant) & 2.068 & .439 & & 4.708 & .000 \\
\hline & Vision_for_growth & .554 & .122 & .539 & 4.527 & .000 \\
\hline \multirow[t]{3}{*}{2} & (Constant) & 1.557 & .487 & & 3.197 & .002 \\
\hline & Vision_for_growth & .428 & .132 & .417 & 3.238 & .002 \\
\hline & Calculated_risk_taking & .259 & .121 & .275 & 2.135 & .038 \\
\hline \multirow[t]{4}{*}{3} & (Constant) & 2.655 & .577 & & 4.601 & .000 \\
\hline & Vision_for_growth & .629 & .139 & .612 & 4.526 & .000 \\
\hline & Calculated_risk_taking & .447 & .128 & .475 & 3.492 & .001 \\
\hline & Opportunity_recognition & -1.077 & .354 & -.467 & -3.045 & .004 \\
\hline
\end{tabular}

a. Dependent Variable: Performance_index

3.6.2 The Mediating Effect of Innovation on the Relationship between Entrepreneurial Orientation and Performance of Value-system Actors

The second objective was to determine whether innovation mediates the relationship between entrepreneurial orientation and the performance of value-system actors in leather industry in Kenya. The following null hypothesis formulated:

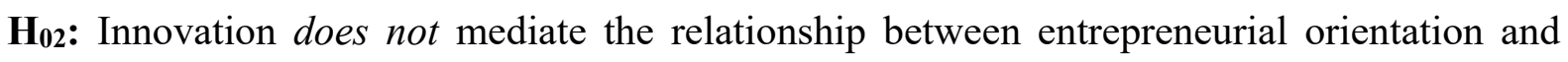
performance of value-system actors in Kenya's leather industry.

$\mathbf{H}_{\mathbf{a} 2}$ : Innovation mediates the relationship between entrepreneurial orientation and performance of value-system actors in Kenya's leather industry.

To establish the mediation effect, Baron and Kenny's (Kenney, 2016) causal step approach was used. The three dimensions of entrepreneurial competence were first averaged into an index representing a single second-order latent construct before regression on the mediating and dependent variables. The correlation between entrepreneurial competence and performance of value-system actors was initially tested before tests for mediation were performed. Pearson Coefficient of 0.675 , and $p$-value of 0.000 (2-tailed test), the correlation was found to be statistically significant. 


\section{Macrothink}

Journal of Entrepreneurship and Business Innovation

ISSN 2332-8851

3.6.2.1 Relationship between Entrepreneurial Orientation and Performance of Value-system Actors

Table 6 shows results of the first step testing effect of entrepreneurial orientation as a latent second-order variable on performance of value-system actors. R-squared obtained from regression analysis was 0.456 , meaning that the Entrepreneurial Orientation was able to explain 45.6\% variations in the Performance of value-system actors in leather industry in Kenya while the rest are explained by the error term. The regression model was significant $(\mathrm{F}=41.94, p$-value 00.000). Therefore, Entrepreneurial Orientation was a significant determinant of Performance of value-system actors in the leather industry in Kenya at $p<0.05$ level of significance. The regression equation obtained from this output was:

$$
\text { Performance }=1.706+1.188 \text { Entrepreneurial Orientation }
$$

Table 6. Regression results for the effect of entrepreneurial orientation and performance of value-system actors

\section{Coefficients(a)}

\begin{tabular}{lllllll}
\hline \multirow{2}{*}{ Model } & & \multicolumn{2}{l}{$\begin{array}{l}\text { Unstandardized } \\
\text { Coefficients }\end{array}$} & $\begin{array}{l}\text { Standardized } \\
\text { Coefficients }\end{array}$ & t & Sig. \\
& & B & $\begin{array}{l}\text { Std. } \\
\text { Error }\end{array}$ & Beta & B & Std. \\
& & 1.706 & .366 & & 4.666 & .000 \\
\hline $1 \quad$ & (Constant) & 1.188 & .184 & .675 & 6.476 & .000 \\
\hline
\end{tabular}

a Dependent Variable: Performance_index.

3.6.2.2 Relationship between Entrepreneurial Orientation and Innovation by Value-system Actors

In the second step, regression analysis resulting showed Entrepreneurial Orientation was able to explain $24.2 \%$ variations in the Innovation in leather industry in Kenya while the rest are explained by the error term $(\mathrm{F}=15.944, p$-value $=0.000)$ which implied that the regression model was significant. The coefficients in the output were significant as shown in Table 7 and the regression equation obtained was:

$$
\text { Innovation }=2.771+0.959 \text { Entrepreneurial Orientation. }
$$

Therefore, entrepreneurial orientation determined innovation of value-system actors in the leather industry in Kenya at $p<0.05$ level of significance. 
Table 7. Regression results for the effect of entrepreneurial orientation and innovation by value-system actors

\section{Coefficients(a)}

\begin{tabular}{lllllll}
\hline \multirow{2}{*}{ Model } & & \multicolumn{2}{c}{$\begin{array}{l}\text { Unstandardized } \\
\text { Coefficients }\end{array}$} & $\begin{array}{l}\text { Standardized } \\
\text { Coefficients }\end{array}$ & t & Sig. \\
& & B & $\begin{array}{l}\text { Std. } \\
\text { Error }\end{array}$ & Beta & B & Std. \\
& & Error & \\
\hline 1 & (Constant) & 2.771 & .478 & & 5.794 & .000 \\
& Entrepreneurial_orientation & .959 & .240 & .492 & 3.993 & .000 \\
\hline
\end{tabular}

a Dependent Variable: innovation_index.

\subsubsection{Relationship between Innovation and Performance of Value-system Actors}

The third step tested the effect of innovation on performance of value-system actors. Innovation was able to explain $40.7 \%$ variations in the Performance of value systems in leather industry in Kenya while the rest are explained by the error term. The F-statistic is 34.376 with a $p$-value of 0.000 which implies that the regression model is significant. Coefficients were significant in the regression model as shown in Table 8 . Therefore, at $p<0.05$ level of significance, innovation determined Performance of value-system actors in Kenya's leather industry. The regression equation obtained from this output was:

$$
\text { Performance }=1.338+0.576 \text { Innovation }
$$

Table 8. Regression Results for the Effect of Innovation and Performance of Value-system Actors

\section{Coefficients $^{\mathrm{a}}$}

\begin{tabular}{|c|c|c|c|c|c|c|}
\hline \multirow[t]{2}{*}{ Model } & & \multicolumn{2}{|c|}{$\begin{array}{l}\text { Unstandardized } \\
\text { Coefficients }\end{array}$} & \multirow{2}{*}{$\begin{array}{l}\text { Standardized } \\
\text { Coefficients } \\
\text { Beta }\end{array}$} & \multirow[t]{2}{*}{$\mathbf{T}$} & \multirow[t]{2}{*}{ Sig. } \\
\hline & & B & Std. Error & & & \\
\hline \multirow{2}{*}{1} & (Constant) & 1.338 & .464 & & 2.886 & .006 \\
\hline & Innovation index & .576 & .098 & .638 & 5.863 & .000 \\
\hline
\end{tabular}

a. Dependent Variable: Performance_index 


\section{Macrothink}

Journal of Entrepreneurship and Business Innovation

ISSN 2332-8851

3.6.2.4 Multiple Linear Regression of Entrepreneurial Orientation and Innovation on Performance of Value-system Actors

The fourth step tested the effect of both entrepreneurial orientation and innovation on performance. As shown in Table 9, entrepreneurial orientation and innovation accounted for $58 \%$ of variation in performance (Adjusted $\mathrm{R}^{2}=0.580$ ) and that this relationship was significant $(\mathrm{F}=33.807, p=0.000)$. Coefficients in the model had corresponding $p$-value for were within the acceptable at $p<0.05$ level of significance

Therefore, the regression model equation obtained from these results was:

$$
\text { Performance }=0.839 \text { Entrepreneurial Orientation }+0.364 \text { Innovation }
$$

Significance of the mediator innovation variable in Step 3 where entrepreneurial orientation is controlled shows mediation effect of innovation on the entrepreneurial orientation-performance link is supported. Step 4 where both the independent entrepreneurial orientation and the mediator innovation variables are significant in predicting performance shows that innovation mediates the entrepreneurship-performance link. Significance of the innovation variables in both Steps 3 and 4 shows that innovation partially mediates the entrepreneurial orientation-performance link. The results therefore further support rejection of the null hypothesis and acceptance of the alternative hypothesis at $p<0.05$ level of significance. Therefore, innovation has a significant and partial mediating effect on the entrepreneurial orientation-performance relationship.

Table 9. Regression results for the effect of entrepreneurial orientation and innovation on performance of value-system actors

\section{Coefficients(a)}

\begin{tabular}{lllllll}
\hline $\begin{array}{l}\text { Mode } \\
1\end{array}$ & & \multicolumn{2}{l}{$\begin{array}{l}\text { Unstandardized } \\
\text { Coefficients }\end{array}$} & $\begin{array}{l}\text { Standardized } \\
\text { Coefficients }\end{array}$ & $\mathrm{t}$ & Sig. \\
& & B & Std. Error & Beta & B & Std. Error \\
\hline 1 & $\begin{array}{l}\text { (Constant) } \\
\text { innovation_index }\end{array}$ & .696 & .420 & & 1.658 & .104 \\
& Entrepreneurial_orientation & .839 & .187 & .477 & 3.797 & .000 \\
& & & & & 4.484 & .000 \\
\hline
\end{tabular}

a Dependent Variable: Performance_index.

3.6.2.5 Sobel Test for Mediation between the Entrepreneurial Orientation and Performance Link

To establish the significance of the mediation effect of Innovation on the relationship between entrepreneurial orientation and the performance of value-system actors in leather industry in Kenya, Sobel test was used in the study (Kenny, 2016). 


\section{Macrothink}

The significance is measured by the following formula:

$$
\mathrm{z} \text {-value }=\mathrm{a}^{*} \mathrm{~b} / \mathrm{SQRT}\left(\mathrm{b}^{2 *} \mathrm{sa}^{2}+\mathrm{a}^{2 *} \mathrm{sb}^{2}\right)
$$

Where,

$\mathrm{a}=$ raw (unstandardized) regression coefficient for the association between the independent variable and mediator.

$\mathrm{sa}=$ standard error of $\mathrm{a}$.

$\mathrm{b}=$ raw coefficient for the association between the mediator and the dependent variable (when the intervening variable is also a predictor of the dependent variable).

$\mathrm{sb}=$ standard error of $\mathrm{b}$.

As shown in Table 10, the results indicate that the $Z$-value for the Sobel test $(Z=3.30449610)$ with a $p$-value of 0.00095147 (two-tailed) which is less than the $p<0.05$ test threshold for significance. Therefore, at $p<0.05$ level of significance the null hypothesis is rejected implying that innovation mediates the relationship between entrepreneurial orientation and performance of value-system actors in Kenya's leather industry. On the basis of these statistics, the study confirms that there is a significant mediating effect of innovation on the relationship between entrepreneurial orientation and performance of value-system actors in Kenya's leather industry. The partial mediation effect of innovation on the entrepreneurial orientation and performance link is established in the four sequential steps above (Kenny, 2016).

This study's results therefore are in agreement with previous studies on the determination of performance by innovation and its mediation of the entrepreneurship-performance relationship in business ventures. Regression analysis by Abdilahi, Hassan and Muhumed (2017) showed that innovation, including product innovation, marketing innovation and organizational innovation, significantly affected SME performance. Madhoushi, Sadati, Delavari, Mehdivand and Mihandost (2011), Kraus et al. (2012) Ndubisi and Iftikhar (2012), Kollman and Stockmann (2012), Al-Ansari (2014) have found that innovation to be a significant mediator of entrepreneurial performance. Acs et al. (2015) asserted that innovation is a mediator of growth performance in firms.

Table 10. Results of the Sobel test

\begin{tabular}{llll}
\hline Mediation & $\begin{array}{l}\text { Z-value for the } \\
\text { Sobel test }\end{array}$ & $\begin{array}{l}\text { One-tailed } \\
\text { probability }\end{array}$ & $\begin{array}{l}\text { Two-tailed } \\
\text { probability }\end{array}$ \\
\hline $\begin{array}{l}\text { Entrepreneurial Orientation } \\
\text { and performance mediated } \\
\text { by innovation }\end{array}$ & 3.30449610 & 0.00047574 & 0.00095147 \\
\hline
\end{tabular}




\section{Macrothink}

Journal of Entrepreneurship and Business Innovation

ISSN 2332-8851

2021, Vol. 8, No. 2

The regression analysis confirmed a direct and a partially innovation-mediated relationship between vision for growth and performance of value-system actors in Kenya's leather industry as hypothesized. The resultant optimal regression equation for relationship was therefore:

$$
P=0.839 E O+0.364 I+\varepsilon
$$

Where,

$E O=$ Entrepreneurial orientation of value-system actors

$I=$ Innovation by value-system actors

$P=$ Performance of value-system actors

$E=$ Error term.

Figure 4 shows a conceptual framework of the optimal empirical model for the relationship between entrepreneurial orientation, innovation and performance factors in a firm. 


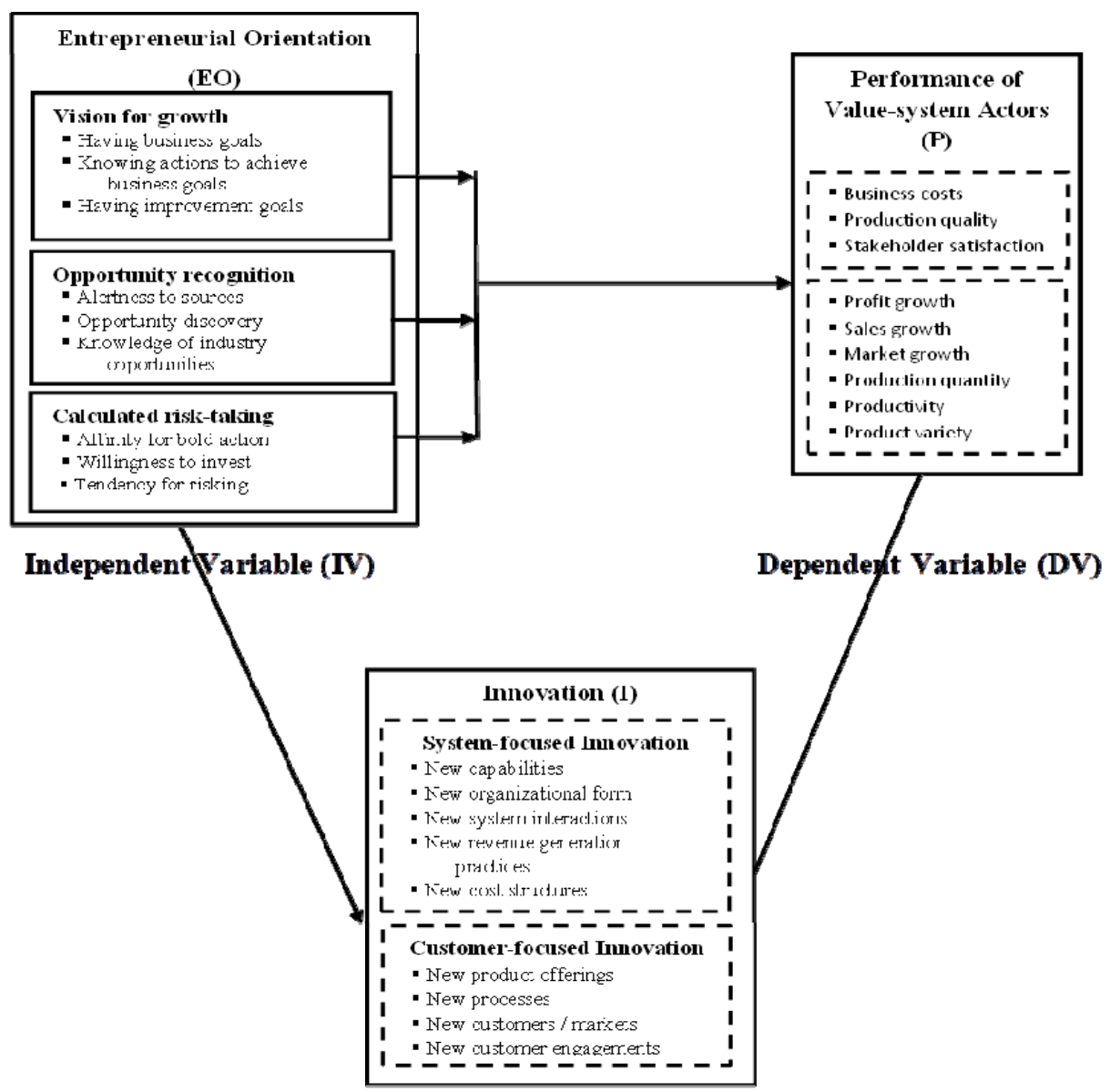

Mediating Variable (MV)

Figure 4. Empirical model showing partial mediating effect of innovation on the relationship between entrepreneurial orientation and firm performance

\section{Discussion}

\subsection{Summary of Discussion and Practical Implications}

This study provides empirical evidence for validity of entrepreneurial orientation as a psychological construct and its relationship with entrepreneurship outcomes. The findings of this research are consistent with past scholarship, both theoretical and empirical. Entrepreneurial orientation can be studied as a multi-dimensional second-order latent factor comprising three dimensions, namely vision for growth, opportunity recognition and calculated risk-taking. Innovation can be studied as an outcome of entrepreneurship comprising system-oriented and customer-oriented innovations as dimensions. Performance can be understood as having two components. For the performance variable, the dimensionality may have been due to the mixed design of items in the measurement instrument. 
Both entrepreneurial orientation and innovation were significant determinants of performance of value-system actors in Kenya's leather industry. Further, innovation partially mediated the entrepreneurial orientation and performance link.

The study findings can find practical use in guiding entrepreneurship research, training and policy. The study contributes to our theoretical understanding of entrepreneurship from a cognitive approach in departing from the commonly studied models by including vision for growth as a factor. It provides researchers, educators and policy makers with a theoretical model for measuring entrepreneurial dispositions and their outcomes for research or interventions in entrepreneurship.

Scholars can use the model to investigate the entrepreneurial orientation of individuals and its outcomes of innovation and performance at firm, ecosystem-actor or industry levels. The relationships studied here can be tested in different firms or industries to inform interventions needed especially in less-studied regions such as Africa. This would contribute to understanding the role of entrepreneurial dispositions in economic performance, especially using broad outcome measures. In entrepreneurship development, educators and trainers can apply the model in guiding students and practitioners towards having a vision, looking for opportunities and taking affordable risks for effectiveness in entrepreneurial endeavours. Further, policy makers can use the model to develop programs for enhancing entrepreneurial performance of ventures in an industry, especially the use of a holistic ecosystem approach. For example, enhancing development of goals for change and growth or sharing information for awareness of industry dynamics can lead to innovations. This can improve overall an industry's competitiveness in the contemporary globalized economic order.

\subsection{Study Limitations and Areas of Further Research}

This research was limited in scope to one industry, a small sample and possible respondents at various value-system actor roles. Analysis was not possible at value-system roles or industry levels and therefore conclusions were limited to the firm-level. The study also relied on self-reported performance measures due to limited access to secondary data and poor record-keeping by SMEs owners. Given the broad ecosystem perspective adopted in this study, possible extraneous factors that may influence the variables are acknowledged but not studied. These include cultural, government / political, institutional (e.g. financial or academic), market dynamics, technological, ecological (climatic) issues that may affect individual or enterprise characteristics.

Further research can apply the model validity in larger samples and different firms or industry-ecosystems contexts to test its validity. Such studies can not only analyse data at firm-level but also at value-system player roles and the industry levels. This would further our understanding of the constructs applied here, in particular the significance of vision for growth as a dimension of entrepreneurial orientation.

\subsection{Conclusion}

Empirical evidence from this study showed that Entrepreneurial Orientation can be studied as a psychological as opposed to a behavioural construct. Entrepreneurial Orientation was a 
determinant of Performance of businesses in Kenya's leather industry and this relationship was partially mediated by Innovation. Innovation and Performance comprised two dimensions each. Entrepreneurial orientation and innovation were therefore found to be important predictors of performance for value-system actors in an industry ecosystem.

These results were consistent with theoretical postulations and past studies in entrepreneurship. The factors established here could therefore find application in entrepreneurship training, practice and policy intervention to build entrepreneurial ecosystems for competitiveness in a globalized economic order. This study recommends further research on the relationship between entrepreneurial orientation, innovation and performance at ecosystem level in diverse industries and at multiple levels of analysis. Vision for growth could also be investigated further as dimension of entrepreneurial orientation.

\section{Disclosure of Conflict of Interests}

The author declares that there are no competing interests associated with this manuscript.

\section{Funding}

The author declares that there was no funding associated with this manuscript.

\section{References}

Abdilahi, M. H., Hassan, A. A., \& Muhamed, M. M. (2017). The Impact of Innovation on Small and Medium Enterprises Performance: Empirical Evidence from Hargeisa, Somaliland. International Journal of Academic Research in Business and Social Science, 7(8). http://dx.doi.org/10.6007/IJARBSS/v7-i8/3202.

Acs, Z. J., Szerb, L., \& Autio, E. (2015). Global Entrepreneurship Index 2015. Washington: The Global Entrepreneurship and Development Institute (GEDI). Retrieved from https:/thegedi.org/global-entrepreneurship-and-development-index/

Al-Ansari, Y. D. Y. (2014). Innovation Practices as a Path to Business Growth Performance: A Study of Small and Medium-sized Firms in the Emerging UAE Market. (Doctoral Thesis) Southern Cross University, Lismore, NSW. Retrieved from https://epubs.scu.edu.au/theses/355/

Amit, R., \& Zott, C. (2012). Creating Value Through Business Model Innovation. MIT Sloan Management Review, Spring, 53(3), 41-49. Retrieved from https://sloanreview.mit.edu/article/creating-value-through-business-model-innovation/

Amstrong, S. J., \& Hird, A. (2009). Cognitive Style and Entrepreneurial Drive of New and Mature Business Owner-managers. Journal of Business and Psychology, 24(4), 419-430. Retrieved from http://link.springer.com/article/10.1007/s10869-009-9114-4

Audretsch, D. (2007). The Entrepreneurial Society. New York: Oxford University Press

Bakar, L. A., \& Zainol, F. A. (2015). Vision, innovation, pro-activeness, risk-taking and SMEs Performance: A Proposed Hypothetical Relationship in Nigeria. International Journal of Academic Research in Economics and Management Sciences, 4(2), 45-53. http://dx.doi.org/10.6007/IJAREMS/v4-i2/1665

Banga, R., Kumar, D., \& Cobbina, P. (2015). Trade-led Regional Value Chains in 


\section{Ml Macrothink}

Journal of Entrepreneurship and Business Innovation ISSN 2332-8851

Sub-Saharan Africa: Case Study on the Leather Sector. Commonwealth Trade Policy Discussion Papers 2015/02. London: Commonwealth Secretariat. Retrieved from http://www.thecommonwealth-ilibrary.org/commonwealth/trade/trade-led-regional-value-chai ns-in-sub-saharan-africa_5js6b112tf7f-en;jsessionid=cia9hpbjnegpn.x-oecd-live-02?citeforma $\mathrm{t}=$ ris\&igo $=$ commonwealth

Baron, R. A., \& Ensley, M. D. (2006). Opportunity Recognition as Detection of Meaningful Pattern: Evidence from Comparisons of Novice and Experienced Entrepreneurs. Management Science, 52(9), 1331-1344. https://doi.org/10.1287/mnsc.1060.0583

Bartlett, M. S. (1954). A Note on the Multiplying Factors for Various Chi Square Approximations. Journal of the Royal Statistical Society. Series B (Methodological), 16(2), 296-298. Retrieved from https://www.jstor.org/stable/pdf/2984057.pdf

Bashir, M., \& Verma, R. (2017). Why Business Model Innovation Is the New Competitive Advantage. The IUP Journal of Business Strategy, 14(1), 7-17.

Baum, J. R., Locke, E. A., \& Smith, K. G. (2001). A Multidimensional Model of Venture Growth. Academy of Management Journal, 44(2). https://www.jstor.org/stable/3069456

Bjerke, B. (2007). Understanding Entrepreneurship. Cheltenham, UK: Edward Elgar Publishing Limited.

Bless, C., Higson-Smith, C., \& Kagee, A. (2009). Fundamentals of Social Research Methods: An African Perspective. Cape Town: Juta \& Co. Ltd.

Bolton, D. L., \& Lane, M. D. (2012). Individual Entrepreneurial Orientation: Development of a Measurement Instrument. Education and Training, 54(2/3), 219-233. Retrieved from http://www.emeraldinsight.com/0040-0912.htm

Bryman, A. (2012). Social Research Methods (4th ed.). New York: Oxford University Press.

Carland J. W., Carland J. A., \& Ensley M. (2002) Hunting the Heffalump: The Theoretical Basis and Dimensionality of the Carland Entrepreneurial Index. Academy of Entrepreneurship Journal, 7(2), 51-84. Retrieved from http://www.freepatentsonline.com/article/Academy-EntrepreneurshipJournal/166778566.html Chi-hsiang, C. (2015). Effects of Shared Vision and Integrations on Entrepreneurial Performance. Chinese Management Studies, 9(2), 150-175. https://doi.org/full/10.1108/CMS-04-2013-0057

Clauss, T. (2016). Measuring Business Model Innovation: Conceptualization, Scale Development, and Proof of Performance. R\&D Management, 47(3), 385-403. http://onlinelibrary.wiley.com/doi/10.1111/radm.12186/pdf

Cohen, B. (2006). Sustainable Valley Entrepreneurial Ecosystems. Business Strategy and the Environment, 15(1), 1-14. https://doi.org/10.1002/bse.428

Colapinto, C., \& Porlezza, C. (2012). Innovation in Creative Industries: From the Quadruple Helix Model to the Systems Theory (Abstract). Journal of the Knowledge Economy 3(4), 343-353. Retrieved from http://link.springer.com.vpn.jkuat.ac.ke/article/10.1007/s13132-011-0051-x 
Costello, A. B., \& Osborne, J. W. (2005). Best Practices in Exploratory Factor Analysis: Four Recommendations for Getting the Most from Your Analysis. Practical Assessment, Research \& Evaluation, 10(7). http://pareonline.net/pdf/v10n7.pdf

Covin, J. G., \& Wales, W. J. (2012). The Measurement of Entrepreneurial Orientation. Entrepreneurship Theory and Practice 36(4). https://doi.org/10.1111/j.1540-6520.2010.00432.x1

Dinh, H. T., \& Clarke, R. G. G. (Eds). (2012). Performance of Manufacturing Firms in Africa: An Empirical Analysis. Washington, DC: World Bank. https://openknowledge.worldbank.org/handle/10986/11959

Ensley, M. D., Carland, J. W., \& Carland, J. C. (2000). Investigating the Existence of the Lead Entrepreneur. Journal of Small Business Management, 38(4), 59-77. Retrieved from https://search.proquest.com/openview/2b6256df49cefe596125f2d7395d6c64/1?pq-origsite $=\mathrm{g}$ scholar\&cbl $=49244$

Florin, J., Karri, R., \& Rossiter, N. (2007). Fostering Entrepreneurial Drive in Business Education: An Attitudinal Approach. Journal of Management Education, 31(1). Organizational Behaviour Teaching Society. https://doi.org/abs/10.1177/1052562905282023

Garson, D. G., \& Statistical Associates Publishing (SAP) (2012). Testing Statistical Assumptions. Statistical Associates Publishing. Retrieved from http://www.statisticalassociates.com/assumptions.pdf

Gupta, R., \& Gupta, P. (2013) Individual Dimensions of Entrepreneurial Orientation (EO) Construct, Resources and Firm Growth: Evidence from Indian Small \& Medium Enterprises (SMES) (Summary). Frontiers of Entrepreneurship Research, 33(12), 5. Retrieved from http://digitalknowledge.babson.edu/fer/vol33/iss 12/5

Hair, J. F., Black, W. C., Babin, B. J., \& Anderson, R. E. (2014). Multivariate Data Analysis, (7th ed.). Essex: Pearson Education Limited.

Hamel, G., \& Prahalad, C. K. (1996). Competing for the Future. Boston: Harvard Business

Hansen, E. R., Moon, Y., \& Mogollon, M. P. (2015). Kenya - Leather Industry: Diagnosis, Strategy, and Action Plan. Washington, D.C.: World Bank Group. Retrieved from http://documents.worldbank.org/curated/en/397331468001167011/Kenya-Leather-industry-di agnosis-strategy-and-action-plan

Jain, R. K. (2011). Entrepreneurial Competencies: A Meta-analysis and Comprehensive Conceptualization for Future Research. SAGE Publications, 15(2), 127-152. https://doi.org/10.1177/097226291101500205

Kaiser, H. F. (1974). An Index of Factorial Simplicity. Psychometrika, 39(1), 31-36. Retrieved from https://jaltcu.org/files/articles/Kaiser1974 an index of factorial simplicity.pdf

Kantabutra, S. \& Avery, G. C. (2010). The Power of Vision: Statements that Resonate. Journal of Business Strategy, 31(1), 37-45. https://doi.org/10.1108/02756661011012769.

Keeley, L., Walters, H., \& Pikkel, R. and Quinn, B. (2013). Ten Types of Innovation: The Discipline of Building Breakthroughs. New Jersey: John Wiley \& Sons, Inc. 
Kenny, D. A. (2016). Mediation. Webpage. Retrieved from http://davidakenny.net/cm/mediate.htm

Kenya Institute of Public Policy Research and Analysis [KIPPRA]. (2016). Kenya Economic Report 2016. Nairobi: Retrieved from https://kippra.or.ke/index.php/tenders/download/4-kenya-economic-report/9-ker2016

Kollmann, T., \& Stockmann, C. (2012). Filling the Entrepreneurial Orientation-Performance Gap: The Mediating Effects of Exploratory and Exploitative Innovations. Entrepreneurship Theory and Practice, 38(5), 1001-1026. Retrieved from http://onlinelibrary.wiley.com/doi/10.1111/j.1540-6520.2012.00530.x/full

Kothari, C. R., \& Gaurav, G. (2014). Research Methodology: Methods and Techniques (3rd ed.). New Delhi: NewAge International Limited Publishers.

Kraus, S., Rigtering, J. P. C., Hughes, M., \& Hosman, V. (2012). Entrepreneurial Orientation and the Business Performance of SMEs: A Quantitative Study from the Netherlands. Review of Managerial Science, 6(2), 161-182. Retrieved from http://link.springer.com/article/10.1007/s11846-011-0062-9

Kreiser, P. M., Marino, L. D., Kuratko, D. F., \& Weaver, K. M. (2012) Disaggregating Entrepreneurial Orientation: The Non-linear Impact of Innovativeness, Pro-activeness and Risk-taking on SME Performance. Small Business Economics, 40, 273-291. https://doi.org/10.1007/s11187-012-9460-x

Krueger, N. F., Reilly, M. D., \& Carsrud, A. L. (2000). Competing Models of Entrepreneurial Intentions. Journal of Business Venturing, 15(5-6), 411-432. https://doi.org/10.1016/S0883-9026(98)00033-0

Kshetri, N. (2014). Developing Successful Entrepreneurial Ecosystems: Lessons from a Comparison of an Asian Tiger and a Baltic Tiger. Baltic Journal of Management, 9(3), 330-356. Retrieved from https://www.emerald.com/insight/content/doi/10.1108/BJM-09-2013-0146/full/html

Kuratko, D. F. (2014). Entrepreneurship: Theory, Process and Practice (9th ed.). Mason, Ohio, USA: South-Western, Thomson Learning.

Lans, T., Verstegen, J., \& Mulder, M. (2011). Analyzing, Pursuing and Networking: Towards a Validated Three-factor Framework for Entrepreneurial Competence from a Small Firm Perspective. International Small Business Journal, 29(6), 695-713. https://doi.org/10.1177/0266242610369737

Leech, N. L., Barrett, K. C., \& Morgan, G. A. (2005). SPSS for Intermediate Statistics: Use and Interpretation (2nd ed.). Mahwah, New Jersey: Lawrence Erlbaum Associates, Publishers.

Locke, E. A., \& Latham, G. P. (2006). New Directions in Goal-Setting Theory. Current Directions in Psychological Science, 15(5), 265-268. Retrieved from http://cmaleadershipconsultants.com/wp-content/uploads/2015/02/New-directions-in-goal-set ting.pdf

Lomberg, C., Urbig, D., Stockmann, C., Marino, L. D., \& Dickson, P. H. (2016). 
Entrepreneurial Orientation: The Dimensions' Shared Effects in Explaining Firm

Performance. Entrepreneurship Theory and Practice. Retrieved from http://onlinelibrary.wiley.com/doi/10.1111/etap.12237/pdf

Lumpkin, G. T., \& Dess, G. G. (1996). Clarifying the Entrepreneurial Orientation Construct and Linking It to Performance. The Academy of Management Review, 21(1), 135-172. Retrieved from http://www.jstor.org/stable/258632

Lumpkin, G. T., \& Frese, M. (2009). Entrepreneurial Orientation and Business Performance: An Assessment of Past Research and Suggestions for the Future. Entrepreneurship Theory and Practice, 33(3), 761-787. https://doi.org/10.1111/j.1540-6520.2009.00308.x

Madhoushi, M., Sadati, A., Delavari, H., Mehdivand, M., \& Mihandost, R. (2011). Entrepreneurial Orientation and Innovation Performance: The Mediating Role of Knowledge Management. Asian Journal of Business Management, 3(4), 310-316.

McMullan, W. E., \& Kenworthy, T. P. (2015). Creativity and Entrepreneurial Performance- A General Scientific Theory. Journal of Business and Psychology, 24, 419. https://doi.org/10.1007/s10869-009-9114

Mekonnen, H., Mudungwe, N., \& Mwinyihija, M. (2014). A Quantitative Analysis Determining the Performance of Small and Medium Enterprises (SMEs) in Leather Footwear Production in Selected Common Market for Eastern and Southern African (COMESA) Countries. (Abstract). Journal of Africa Leather and Leather Products Advances, 1(1), 1-23. https://doi.org/10.15677/jallpa.2014.v1i1.6

Ming, C., \& Yang, Y. (2009). Typology and Performance of New Ventures in Taiwan: A model Based on Opportunity Recognition and Entrepreneurial Creativity. International Journal of Entrepreneurial Behavior \& Research, 15(5), 398-414. http://www.emeraldinsight.com/doi/full/10.1108/13552550910982997.

Ministry of Industrialization Trade and Cooperatives [MOIT\&C]. (2016). Kenya's Industrial Transformation Programme. Retrieved from http://www.industrialization.go.ke/index.php/downloads/282-kenya-s-industrial-transformatio n-programme

Mohammed, K., Ibrahim, H. I., \& Shah, K. A. M. (2017). Empirical Evidence of Entrepreneurial Competencies and Firm Performance: A Study of Women Entrepreneurs of Nigeria. International Journal of Entrepreneurial Knowledge, 5(1), 49-61. Retrieved from https://ijek.org/index.php/IJEK/article/view/53

Mwinyihija, M. (2015). Evaluation of Competitiveness Responses from the Leather Value Chain Strata in Kenya. Research in Business and Management 2(1), 1-24. https://doi.org/10.5296/rbm.v2i1.xxxx

Nafukho, F. M., \& Muyia, M. A. H. (2010). Entrepreneurship and Socioeconomic Development in Africa: A Reality or Myth? Journal of European Industrial Training, 34(2), 96-109. http://dx.doi.org/10.1108/03090591011023961

Ndubisi, O. N., \& Iftikhar, K. (2012). Relationship between Entrepreneurship, Innovation and Performance: Comparing Small and Medium-size Enterprises. (Abstract). Journal of 
Research in Marketing and Entrepreneurship, 14(2), 214-236. https://doi.org/10.1108/14715201211271429

Neuman, W. L. (2009). Understanding Research. Boston: Pearson Education, Inc.

Ngugi, J. K., Mcorege, M. O., \& Muiru, J. M. (2013). Influence of Innovativeness on Growth of SMEs in Kenya. International Journal of Business and Social Research (IJBSR), 3(1), 25-31. Retrieved from https://thejournalofbusiness.org/index.php/site/article/download/84/83

Poutziouris, Y. W. P. (2010). Entrepreneurial Risk Taking: Empirical Evidence from UK Family Firms, International Journal of Entrepreneurial Behavior \& Research, 16(5), 370-388. http://dx.doi.org/10.1108/13552551011071841

Puhakka, V. (2002). Entrepreneurial Business Opportunity Recognition. Relationships between Intellectual and Social Capital, Environmental Dynamism, Opportunity Recognition Behavior, and Performance. Unpublished doctoral dissertation, Finland: University of Vaasa.

Rauch, A., \& Frese, M. (2007). Let's Put the Person Back into Entrepreneurship Research: A Meta-analysis on the Relationship between Business Owners' Personality Traits, Business Creation, and Success. European Journal of Work and Organisational Psychology, 16(4), 353-385. https://doi.org/10.1080/13594320701595438

Rauch, A., Wiklund, J., Lumpkin, G. T., \& Frese, M. (2009). Entrepreneurial Orientation and Business Performance: An Assessment of Past Research and Suggestions for the Future. Entrepreneurship Theory and Practice, 33(3), 761-787.

Republic of Kenya [RoK]. (2007). Vision 2030: A Globally Competitive and Prosperous Kenya. Government of Kenya. Retrieved from https://www.opendata.go.ke/

Republic of Kenya [RoK]. (2012). Micro and Small Enterprises Act No. 55 of 2012. Retrieved from http://www.kenyalaw.org

Roach, D. C., Ryman, J., \& Makani, J. (2016). Effectuation, Innovation and Performance in SMEs: an Empirical Study, European Journal of Innovation Management, 19(2), 214-238. https://doi.org/10.1108/EJIM-12-2014-0119

Sahban, M. A., Kumar, D. M., \& Ramalu, S. S. (2014). Entrepreneurial Orientation Instrument (EOI): Integrating Mixed Mode of Research in Instrument Construction. International Journal of Applied Business and Economic Research, 12(3), 759-782.

Sanchez, J. (2012). The Influence of Entrepreneurial Competencies on Small Firm Performance. Revista Latinoamericana de Psicología, 44(2) 165-177. Retrieved from http://publicaciones.konradlorenz.edu.co/index.php/rlpsi/article/view/1040

Santos, J. B. \& Brito, L. A. L. (2012). Toward a Subjective Measurement Model for Firm Performance. Brazilian Administration Review, 9(Special Issue), 95-117. Retrieved from http://www.scielo.br/pdf/bar/v9nspe/07.pdf

Santos, S. C., Caetano, A., Baron, R., \& Curral, L. (2015). Prototype Models of Opportunity Recognition and the Decision to Launch a New Venture, International Journal of Entrepreneurial Behavior \& Research, 21(4), 510-538. http://dx.doi.org/10.1108/IJEBR-04-2014-0058 
Sapsford, R. (2007). Survey Research (2 ${ }^{\text {nd }}$ ed.). London: Sage Publications.

Shane, S. (2000). Prior Knowledge and the Discovery of Entrepreneurial Opportunities. Organisation Science, 11(4), 448-469. http://dx.doi.org/10.1287/orsc.11.4.448.14602

Shwetzer, C., Maritz, A., \& Nguyen, Q. (2019). Entrepreneurial Ecosystems: A Holistic and Dynamic Approach. Journal of Industry-University Collaboration, 1(2), 79-95. http://dx.doi.org/10.1108/JIUC-03-2019-0007

Stephan, U., Hart, M., \& Drews, C. C. (2015). Understanding Motivations for Entrepreneurship: A Review of Recent Research Evidence. Retrieved from http://www.enterpriseresearch.ac.uk/wp-content/uploads/2015/02/Understanding-Motivations -for-Entrepreneurship-Rapid-evidence-assessment-paper.pdf

United Nations. (2008). International Standard Industrial Classification of All Economic $\begin{array}{llll}\text { Activities } & \text { Revision } & \text { Retrieved } & \text { from }\end{array}$ https://unstats.un.org/unsd/publication/seriesm/seriesm_4rev4e.pdf

United Nations Industrial Development Organization (UNIDO]. (2010). Future Trends in the World Leather and Leather Products Industry and Trade. Vienna: UNIDO. Retrieved from $\mathrm{http} / / /$ leatherpanel.org/sites/default/files/publications-attachments/future_trends_in_the_worl d_leather_and_leather_products_industry_and_trade.pdf

Valentinov, V., \& Chatalova, L. (2016). Institutional Economics and Social Dilemmas: A Systems Theory Perspective. Systems Research and Behavioural Science, 33(1), 138-149. https://doi.org/10.1002/sres.2327

Wales, J. W. (2016). Entrepreneurial Orientation: A Review and Synthesis of Promising Research Directions. International Small Business Journal 2016, 32(1), 3-15. Retrieved from https://journals.sagepub.com/doi/10.1177/0266242615613840

Wasdani, K. P., \& Mathew, M. (2014). Potential for Opportunity Recognition along the Stages of Entrepreneurship. Journal of Global Entrepreneurship Research 2(7). http://journal-jger.springeropen.com/articles/10.1186/2251-7316-2-7

Welter, F. (2010) Contextualizing Entrepreneurship - Conceptual Challenges and Ways Forward. Entrepreneurship Theory and Practice. http://dx.doi.org/10.1111/j.1540-6520.2010.00427.x

Wiklund, J., \& Shepherd, D. (2003). Knowledge-based Resources, Entrepreneurial Orientation, and the Performance of Small and Medium-sized Business. Strategic Management Journal, 24, 1307-1314. https://doi.org/10.1002/smj.360

Wiklund, J., \& Shepherd, D. (2005). Entrepreneurial Orientation and Small Business Performance: A Configuration Approach. Journal of Business Venturing, 20(1), 71-91. https://doi.org.10.1016/j.jbusvent.2004.01.001

Zhang, H., Zhang, T., Cai, H., Li, Y., Huang, W. W., \& Xu, D. (2014). Proposing and Validating a Five-dimensional Scale for Measuring Entrepreneurial Orientation: An Empirical Study. Journal of Entrepreneurship in Emerging Economies, 6(2), 102-121. https://doi.org/10.1108/JEEE-03-2014-0004 


\section{Macrothink}

Journal of Entrepreneurship and Business Innovation

ISSN 2332-8851 2021, Vol. 8, No. 2

Zhao, H., Seibert, S., \& Lumpkin, G. (2010). The Relationship of Personality to Entrepreneurial Intentions and Performance: A Meta-analytic Review. Journal of Management, 36(2), 381-404. Southern Management Association. http://dx.doi.org/10.1108/13552550510580825

\section{Copyrights}

Copyright for this article is retained by the author(s), with first publication rights granted to the journal.

This is an open-access article distributed under the terms and conditions of the Creative Commons Attribution license (http://creativecommons.org/licenses/by/4.0/) 